\title{
PENGARUH PADUAN MIKRO Fe Cr DENGAN METODE ULTRASONIK PADA PEMBENTUKAN BONGKAH Fr Cr MELALUI VARIASI SUHU SINTERING
}

\author{
Kusdi Prijono $^{(1)}$, Amin Suhadi ${ }^{(2)}$ \\ Badan Pengkajian dan Penerapan Teknologi (BPPT) ${ }^{(1)}$, \\ Badan Pengkajian dan Penerapan Teknologi (BPPT) ${ }^{(2)}$
}

\begin{abstract}
ABSTRAK
Fe-Cr merupakan paduan yang memiliki ketahanan pada suhu tinggi dan kemampuan yang dapat digunakan sebagai interkonek pada sel bakar Solid Oxide Fuel Cell (SOFC). Pada penelitian ini telah dilakukan sintesis bongkah paduan $\mathrm{Fe}-\mathrm{Cr}$ dengan menggunakan serbuk paduan mikro $\mathrm{Fe}-\mathrm{Cr}$ hasil sintesis dengan metode ultrasonik. Metode ultrasonik dimanfaatkan untuk sintesis paduan mikro $\mathrm{Fe}-\mathrm{Cr}$ melalui penggunaan gelombang suara ultrasonik. Langkah yang dilakukan adalah memadatkan partikel paduan mikro $\mathrm{Fe}-\mathrm{Cr}$ dengan kompaksi tanpa lubrikan, hasil kompaksi dimasukan kedalam kapsul kaca kuarsa selanjutnya dilakukan proses variasi sintering $1100^{\circ} \mathrm{C}, 1200^{\circ} \mathrm{C}$ dan $1300^{\circ} \mathrm{C}$ pada kondisi suhu maximal ditahan selama 1 jam ,lalu didinginkan secara normal dalam tungku. Karakterisasi strukturmikro dilakukan dengan Scanning Electron Microscopy (SEM), Energy Dispersive X-Ray Spectroscopy (SEM-EDS), X-Ray Diffraction (XRD) disertai analisis dengan metode MAUD (Material Analisys Using Diffraction) dan pengukuran Nilai kekerasan sesungguhnya. Partikel paduan mikro $\mathrm{Fe}-\mathrm{Cr}$ lebih stabil dan konsisten dalam pembentukan fasa bongkah paduan $\mathrm{Fe}-\mathrm{Cr}$ melalui variasi sintering. Diperoleh bongkah paduan Fe-Cr homogen tanpa oksida.
\end{abstract}

Kata kunci: Paduan mikro Fe-Cr, Ultrasonik, Kapsul Kuarsa, Sintering

\section{ABSTRACT}

$\mathrm{Fe}$-Cr is an alloy that has a high temperature resistance and is potential to be used as an interconnect on Solid Oxide Fuel Cell (SOFC) fuel cells. In this research, $\mathrm{Fe}$-Cr alloys have been synthesized using Super $\mathrm{Fe}-\mathrm{Cr}$ micro alloy powder with ultrasonic method. The ultrasonic method is utilized for the synthesis of Fe-Cr micro alloys through the use of ultrasonic sound waves. The steps taken were the consolidation of the Fe-Cr micro alloy particles through compaction without lubricant, then in a quartz glass capsule a sintering process variation of 11000C, $12000 \mathrm{C}$ and $13000 \mathrm{C}$ at maximum temperature conditions retained for 1 hour, then cooled normally in the furnace. Characterization of microstructure was performed by Scanning Electron Microscopy (SEM), Energy Dispersive XRay Spectroscopy (SEM-EDS), X-Ray Diffraction (XRD) with analysis by MAUD method (Material Analisys Using Diffraction) and actual density measurement. The Fe-Cr micro alloy particles are more stable and consistent in the formation of the $\mathrm{Fe}$-Cr alloy phase via sintering variations. The alloys of $\mathrm{Fe}$-Cr are homogenous without oxide.

\section{PENDAHULUAN}

$\mathrm{Fe}-\mathrm{Cr}$ adalah paduan yang memiliki ketahanan pada suhu tinggi dan potensial digunakan sebagai interkonek pada sel bakar Solid Oxide Fuel Cell(SOFC)[1]. Sintesis paduan Fe-Cr terus dikembangkan untuk mendapatkan metode yang murah, efektif, dan efisien. Metode sintesis paduan $\mathrm{Fe}-\mathrm{Cr}$ yang ada sekarang ini adalah metode peleburan [2], metalurgi serbuk [3] ataupun metode pemaduan mekanik [4]. Metode-metode tersebut memiliki kelemahan karena paduan yang tidak homogen, terdapat oksida, proses panjang dan lama [5]. Serbuk paduan-awal yang homogen diperlukan untuk mengurangi oksidasi selama proses konsolidasi [6]. Sintesis paduan mikro $\mathrm{Fe}-\mathrm{Cr}$ yang homogen bisa dilakukan dengan menggunakan metode ultrasonik. Metode ini memanfaatkan gelombang suara ultrasonik yang dilewatkan pada larutan yaitu melalui proses pembentukan gelembung-gelembung kavitasi 
dalam larutan, kemudian gelembung kavitasi yang runtuh bisa dianggap sebagai reaktor mikro [7]. Runtuhan kavitasi ini bisa menghasilkan suhu ribuan derajat dan tekanan lebih dari seribu bar yang pembentukannya sangat cepat. Disamping itu runtuhan kavitasi juga menghasilkan gelombang kejut $[8,9]$. Gelombang kejut bisa menghasilkan efek mekanis dengan energi besar,sehingga bisa dimanfaatkan untuk homogenisasi dan proses pemaduan logam [10]. Dengan terbentuknya serbuk paduan mikro $\mathrm{Fe}-\mathrm{Cr}$ yang homogen akan memberikan kestabilan dalam pembentukan fasa paduan bongkah $\mathrm{Fe}-\mathrm{Cr}$ yang juga homogen. Disamping itu pemaduan mikro $\mathrm{Fe}-\mathrm{Cr}$ dengan gelombang suara ultrasonik dalam larutan toluen menciptakan tingkat oksidasi lebih rendah dibandingkan dengan jalur konvensional menggunakan air sebagai media pemrosesan [11]. Paduan mikro Fe-Cr telah berhasil diperoleh dengan metode ultrasonik [12]. Partikel paduan mikro $\mathrm{Fe}-\mathrm{Cr}$ memiliki ikatan kuat (merupakan ikatan logam) sehingga pada saat proses sintering partikel $\mathrm{Fe}$ dan $\mathrm{Cr}$ yang ada disekitarnya cenderung lebih mudah berdifusi ke partikel paduan mikro $\mathrm{Fe}-\mathrm{Cr}$. Partikel serbuk paduan mikro $\mathrm{Fe}-\mathrm{Cr}$ adalah homogen, dengan diperoleh dengan menggunakan software Diffraction ), untuk menentukan densitas sesungguhnya (true density) dari green $\mathrm{Fe}-\mathrm{Cr}$ dan bongkah paduan $\mathrm{Fe}-\mathrm{Cr}$ hasil sintering. XRD (Simadzhu XD-610, target $\mathrm{Cu}-$ $\mathrm{K} \alpha$ ) digunakan untuk mendapatkan pola difraksi dan $2 \theta$ puncak difraksi paduan Fe-Cr. SEM-EDS (JEOL, JSM 6510, LA) digunakan untuk mempelajari struktur mikro green $\mathrm{Fe}-\mathrm{Cr}$ dan komposisi unsur bongkah paduan $\mathrm{Fe}-\mathrm{Cr}$.

\section{Cara Kerja}

Rancangan penelitian didahului dengan pengkompaksian terhadap serbuk (ultrasonic 20 dengan Amplitudo 50\% tanpa menggunakan lubrikan. Green $\mathrm{Fe}-\mathrm{Cr}$ diperoleh melalui kompaksi uniaksial pada tekanan $20 \mathrm{MPa}$. Terhadap green Fe$\mathrm{Cr}$, kemudian pengamatan strukturmikro dengan SEM [13]. Langkah selanjutnya adalah proses sintering [14] terhadap green $\mathrm{Fe}-\mathrm{Cr}$ dalam kapsul yang terbuat dari kaca kuarsa menggunakan tungku induksi. Proses sintering dilakukan dengan suhu yang berbeda dan waktu penahan masing masing variasi suhu selama 1 jam (seperti pada Gambar 1) yaitu proses pembakaran sampai $1100^{\circ} \mathrm{C}$ ditahan selama 1 jam dan didinginkan dalam tungku, begitu pula untuk demikian pembentukan bongkah paduan $\mathrm{Fe}-\mathrm{Cr}$ akan homogen dengan fasa stabil. Penelitian ini difokuskan pada konsolidasi paduan mikro $\mathrm{Fe}-\mathrm{Cr}$ hasil perlakuan ultrasonik. Konsolidasi dilakukan dengan kompaksi serbuk partikel paduan mikro FeCr tanpa menambah lubrikan, kemudian dilakukan proses sintering dalam kapsul kaca kuarsa.

\section{METODE PENELITIAN}

\section{Bahan dan Alat}

Serbuk partikel paduan mikro $\mathrm{Fe}-\mathrm{Cr}$ yang digunakan pada penelitian ini adalah serbuk paduan mikro Fe$\mathrm{Cr}$, tipe A hasil perlakuan ultrasonik dalam larutan toluen, Serbuk prekursor $(\mathrm{Fe}, \mathrm{Cr})$ yang digunakan adalah produkAldrich dengan kemurnian 99,9 persen massa, dengan perbandingan $\mathrm{Fe}: \mathrm{Cr}$ yaitu 75:25. Peralatan yang digunakan adalah alat kompaksi, hydraulic press, untuk mendapatkan pelet green FeCr. Dari hasil kompaksi diperoleh type dari ke tiga sampel yang nantinya akan disinter dengan variasi suhu sintering $\left(1100^{\circ} \mathrm{C}, 1200^{\circ} \mathrm{C}\right.$ dan $\left.1300^{\circ} \mathrm{C}\right)$ dimana dari ketiga pellet tersebut ditandai dengan Type B, C dan D. Pengukur densitas yang digunakan

suhu $1200^{\circ} \mathrm{C}$ dan $1300^{\circ} \mathrm{C}$. Untuk pengamatan struktur mikro, dilakukan proses poles menggunakan kertas amplas SiC lalu dengan pasta alumina $(0,05 \mu \mathrm{m})$, proses selanjutnya etsa dengan bahan kimia produk kalling No.2 . Karakteristik hasil sintering diamati dengan SEM-EDS [13], XRD [15,16] berikut analisis penghalusan fasa menggunakan softwarMAUD (Material Analisis Using Diffraction) dan penentuan Nilai kekerasan dari masing masing sampel (B, C dan D).

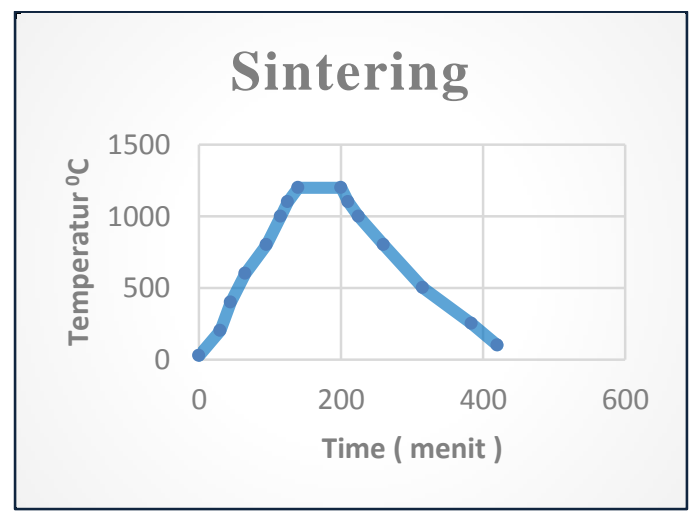

Gambar 1. Pola pemanasan pada Sintering sampel Green 


\section{HASIL DAN PEMBAHASAN}

\section{Konsolidasi Partikel Paduan Mikro Fe-Cr Hasil Perlakuan Ultrasonik Pada Kompaksi}

Untuk sampel pertama, serbuk $\mathrm{Fe}$ dan $\mathrm{Cr}$ secara langsung dicampur dan direndam pada larutan toluenekemudian diproses dengan metode ultrasonik. Serbuk $\mathrm{Fe}$ dan $\mathrm{Cr}$ dicampur dengan komposisi masing-masing $75 \%$ berat dan $25 \%$ berat $\mathrm{Cr}$ masingmasing. Setelah itu, proses ultrasonik dijalankan.

dengan frekuensi $20 \mathrm{kHz}$ sedangkan amplitudo ditetapkan sebesar 50\% dari maksimum. Prosesnya berlangsungselama 20 jam, selanjutnya disebut Sampel A.Strukturmikro serbuk prekursor $\mathrm{Fe}$ dan $\mathrm{Cr}$ ditunjukkan pada Gambar 2. Sementara strukturmikro green $\mathrm{Fe}-\mathrm{Cr}$ hasil kompaksi serbuk dan disinter dengan variasi suhu dengan waktu tahan selama 1 jam pada masing masing suhu, tertera pada Gambar 3. ( Sampel B, C dan D ).

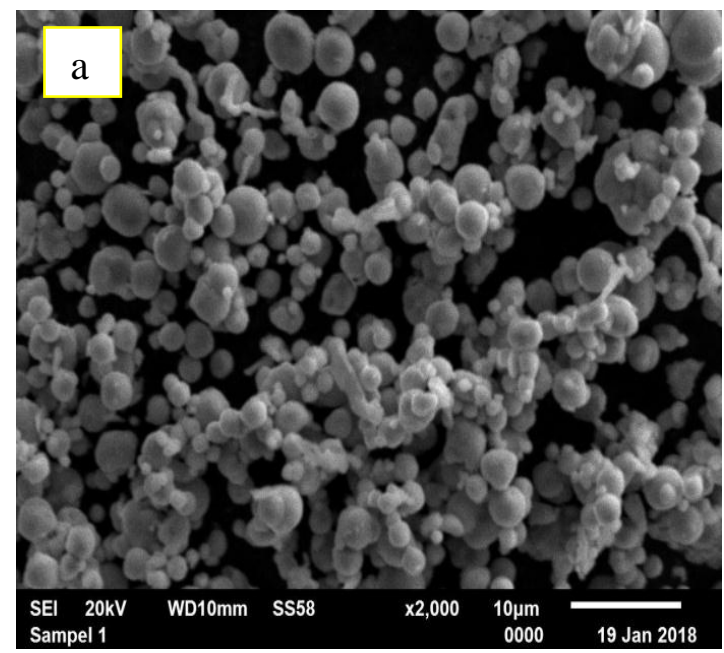

Gambar 2. Struktur mikro serbuk precursor $\mathrm{Fe}$ dan $\mathrm{Cr}$

Dari Gambar 2 terlihat bahwa partikel Fe berbentuk bulat dan bergandengan, Efek kompaksi pada konsolidasi serbuk $\mathrm{Fe}-\mathrm{Cr}$ setelah melalui proses sintering memberikan nilai densitas seperti ditampilkan pada Gambar 3. Sebagaimana terlihat pada Gambar 2, bahwa partikel green tipe A terdiri dari partikel kecil dan partikel besar (aglomerasi $\mathrm{Cr}$ ). Partikel aglomerasi $\mathrm{Cr}$ tampak lebih kompak dibanding hasil kompaksi yang hanya berupa partikel partikel kecil. Partikel kecil dan besar saling mengisi, sehingga densitas tipe A lebih besar. Pada tipe B, C dan D terdapat partikel Fe dan Cr berukuran kecil dimana partikel kecil $\mathrm{Cr}$ ini adalah hasil pecahan partikel besar Cr. Ukuran dan bentuknya lebih homogen, sehingga densitas Tipe B, C dan D lebih rendah dari tipe A. Densitas Tipe A sedikit lebih besar dibanding dengan Tipe B, C dan D (setelah proses sinterin ).

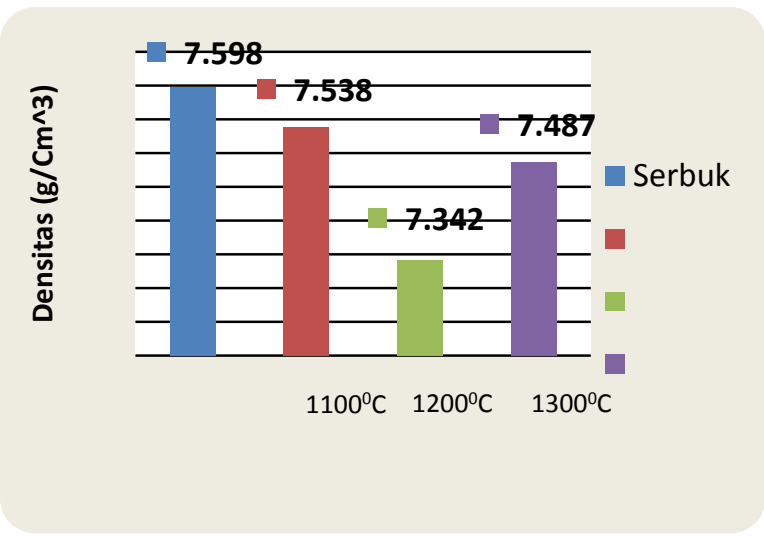

Gambar 3. Densitas Fe-Cr sebelum dan setelah kompaksi dan sintering

\section{Konsolidasi Partikel Paduan Mikro Fe-Cr Pada Variasi Sintering}

Strukturmikro Paduan Fe-Cr Hasil Variasi Sintering Strukturmikro dan komposisi unsur bongkah $\mathrm{Fe}-\mathrm{Cr}$ hasil variasi sintering tertera pada Gambar 4, dan hasil analisis komposisi unsur dengan EDS tertera pada Tabel 1.Pada Gambar 4 (b) terlihat bahwa pada bongkah paduan $\mathrm{Fe}-\mathrm{Cr}$ tipe $\mathrm{B}$ memiliki partikel yang menyatu dan homogen, batas butir tidak begitu jelas namun terlihat pori seperti membentuk batas butir. Terdapat banyak pori berukuran besar dan kecil pada permukaan

sampel.

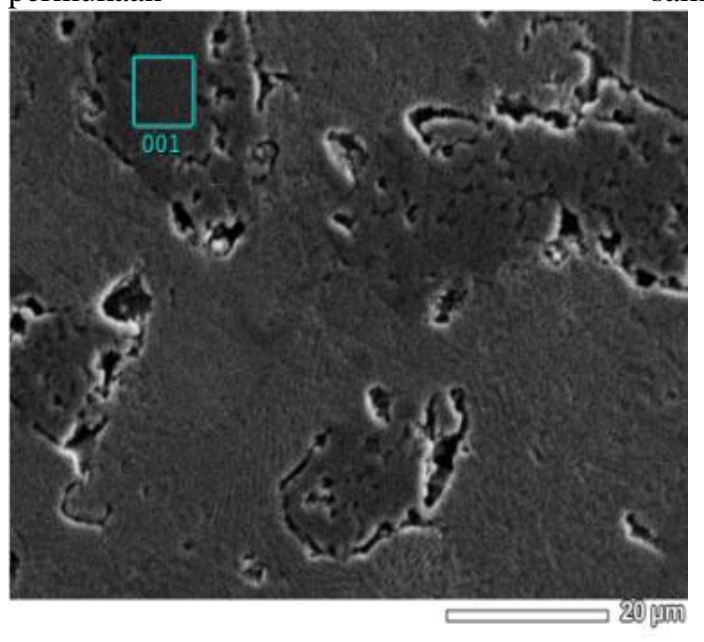



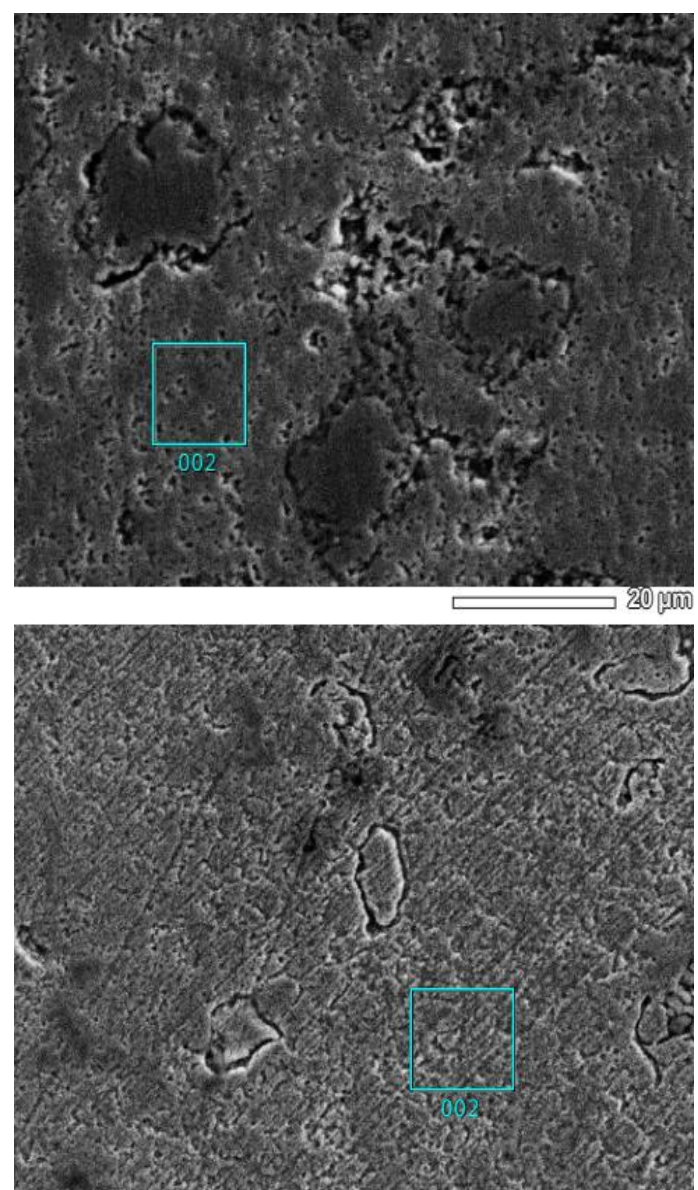

Gambar 4. Strukturmikro bongkah $\mathrm{Fe}-\mathrm{Cr}$ hasil variasi sintering(b) suhu $1100^{\circ} \mathrm{C}$, (c) suhu $1200^{\circ} \mathrm{C}$ (d) suhu $1300^{\circ} \mathrm{C}$

Gambar 4 (b) terlihat bahwa bongkah paduan $\mathrm{Fe}-\mathrm{Cr}$ tipe B memiliki strukturmikro dengan permukaan matriks yang mulus dan homogen yang menunjukkan bahwa partikel menyatu dengan baik. Terdapat pori pada permukaan dan pada sebagian permukaan terdapat bagian yang belum larut dengan sempurna. Sementara pada Gambar 4(c) terlihat bahwa partikel Fe-Cr tipe $\mathrm{C}$ menyatu dengan baik dan homogen, tidak memiliki batas butir yang jelas dan terdapat banyak pori berukuran besar dan kecil pada permukaan. Pada Tabel 1 terlihat bahwa matriks bongkah paduan $\mathrm{Fe}-\mathrm{Cr}$ tipe $\mathrm{D}$ memiliki komposisi paling mendekati dengan komposisi unsur awal paduan, sementara pada bagian yang belum larut

semuanya (posisi 001) terdiri atas kandungan $\mathrm{Cr}$ tinggi. Dari pola strukturmikro Gambar 4 terlihat bahwa bongkah paduan $\mathrm{Fe}-\mathrm{Cr}$ tipe $\mathrm{C}$ dan tipe $\mathrm{B}$, memiliki strukturmikro dengan butir yang besar yang ditunjukkan oleh tidak adanya batas yang jelas antar butir. Terlihat juga bahwa permukaan bongkah paduan $\mathrm{Fe}-\mathrm{Cr}$ tipe $\mathrm{D}$ lebih mulus dibandingkan dengan tipe $\mathrm{B}$ maupun tipe $\mathrm{C}$.

Tabel 1. Komposisi unsur pada daerah tertentu dari bongkah paduan $\mathrm{Fe}-\mathrm{Cr}$ tipe $\mathrm{B}$, tipe $\mathrm{C}$, dan tipe $\mathrm{D}$ hasil variasi disinter.

\begin{tabular}{|l|l|l|}
\hline Posisi & $\begin{array}{l}\mathrm{Fe} \\
(\% \text { massa })\end{array}$ & $\begin{array}{l}\mathrm{Cr} \\
(\% \text { massa })\end{array}$ \\
\hline (b) 001 & 5.39 & 94.61 \\
\hline (c) 002 & 73.84 & 25.16 \\
\hline (d) 002 & 75.28 & 24.72 \\
\hline
\end{tabular}

Pada proses sintering, penahanan suhu pada setiap sintering $\left(1000^{\circ} \mathrm{C}, 1200^{\circ} \mathrm{C}\right.$ dan $\left.1300^{\circ} \mathrm{C}\right)$, memberikan waktu untuk penyatuan partikel yang saling berdekatan sebagai inti awal paduan. Penyatuan pada tahap ini diyakini hanya penyatuan antar permukan membentuk leher antar partikel atau difusi permukaan seperti yang dinyatakan oleh peneliti sebelumnya [19]. Pada tahap ini partikel Fe ataupun $\mathrm{Cr}$ yang ada di sekitar paduan mikro $\mathrm{Fe}-\mathrm{Cr}$ berdifusi permukaan ke partikel paduan mikro $\mathrm{Fe}-\mathrm{Cr}$ (paduan mikro memiliki ikatan kuat yaitu ikatan logam) sehingga melengkapi komposisi paduan mikro yang sudah ada. Pada suhu lebih tinggi $\left(1300^{\circ} \mathrm{C}\right)$ partikel partikel inti awal menyatu membentuk partikel paduan yang lebih besar, terjadi difusi batas butir atau difusi kekisi [19] melepas material dari batas butir menuju ke pengerutan atau pemadatan. Pemadatan pada permukaan bongkah paduan $\mathrm{Fe}-\mathrm{Cr}$ tipe A menyisakan banyak pori kecil ataupun besar pada permukaan bongkah. Dengan variasi sintering, terlihat partikel bongkah paduan pada suhu $1300^{\circ} \mathrm{C}$ Fe-Cr menyatu dengan baik. Pembentukan komposisi matriks bongkah paduan $\mathrm{Fe}$ Cr tipe D melalui proses sintering lebih mendekati ke komposisi awal sebelum sintering. Dengan kata lain, bongkah paduan $\mathrm{Fe}-\mathrm{Cr}$ yang terbentuk melalui proses sintering pada suhu $1300^{\circ} \mathrm{C}$ akan memiliki komposisi lebih mendekati dengan komposisi awal yang diharapkan, dan juga penyatuan lebih baik apabila menggunakan serbuk partikel paduan mikro $\mathrm{Fe}-\mathrm{Cr}$ seutuhnya.

\section{Analisis Fasa Paduan Fe-Cr Hasil Variasi Sintering}


Pola difraksi Fe-Cr hasil variasi sintering disertai dengan posisi sudut $2 \theta$ untuk beberapa puncak dan pola hasil penghalusan menggunakan metode Rietveld tertera pada Gambar 5. Hasil analisis kuantitatif pola difraksi $\mathrm{Fe}-\mathrm{Cr}$ yang disinter dalam kapsul dan yang bersesuaian dengan Gambar 5 ditampilkan pada Tabel 2, disertai juga hasil kuantitatif untuk bahan serbuk pembentuknya yang digunakan pada penelitian ini[12].
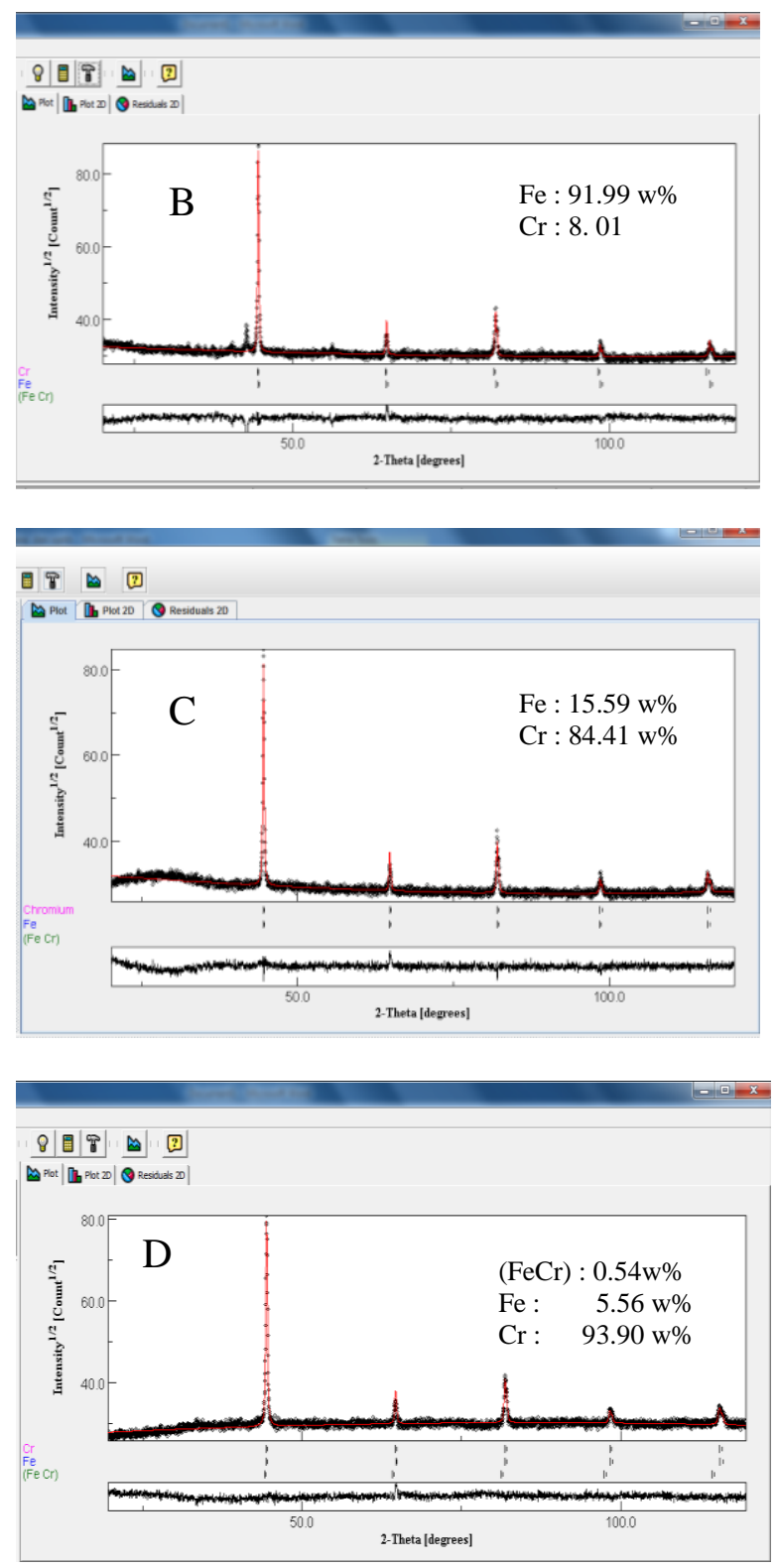

Gambar 5. Pola difraksi bongkah paduan $\mathrm{Fe}-\mathrm{Cr}$ hasil sintering dalam kapsul kuarsa disertai posisi sudut $2 \theta$ dan pola hasil penghalusan menggunakan metode Rietveld untuk tipe B, C dan D
Untuk Variasi sintering, pada penahanan suhu pertama $\left(1100^{\circ} \mathrm{C}\right.$ selama 1 jam $)$ partikel-partikel yang berdekatan terikat dan menjadi intiawal untuk pengikatan selanjutnya pada tahap selanjutnya . Pada tahap ini inti awal pembentuk $\mathrm{Fe}-\mathrm{Cr}$ lebih banyak pada tipe $\mathrm{A}$, oleh karena pada Tipe $\mathrm{B}, \mathrm{C}$ dan $\mathrm{D}$ sebagian partikel sudah menjadi paduan mikro $\mathrm{Fe}-\mathrm{Cr}$ seperti sudah dijelaskan pada alinea awal bagian hasil dan pembahasan ini [12]. Dengan demikian pada saat sintering fraksi massa fasa $\mathrm{Fe}-\mathrm{Cr}$ lebih banyak yang terbentuk pada Tipe A. Dilain pihak pada tipe B, C dan $\mathrm{D}$ pembentukan inti lebih sedikit pada penahanan suhu tahap pertama karena sebagian inti pada awalnya sudah berupa paduan mikro dengan demikian pada tahap selanjutnya fraksi massa fasa Fe-Cr yang terbentuk lebih sedikit. Hasil parameter kisi ini menunjukkan bahwa dengan sintering sampai suhu $1300^{\circ} \mathrm{C}$ terhadap campuran serbuk ( $\mathrm{Fe}, \mathrm{Cr}$, dan paduan mikro $\mathrm{FeCr}$ ) maka terbentuk bongkah paduan fasa $\mathrm{Fe}-\mathrm{Cr}$. Hasil ini juga menunjukkan bahwa fasa paduan $\mathrm{Fe}-\mathrm{Cr}$ yang berasal dari serbuk paduan mikro Fe-Cr seutuhnya (tipe A, hasil perlakuan ultrasonik) lebih konsisten. Hasil-hasil tersebut semakin mempertegas bahwa komposisi bongkah paduan $\mathrm{Fe}$ $\mathrm{Cr}$ adalah lebih homogeny menggunakan serbuk paduan mikro $\mathrm{Fe}-\mathrm{Cr}$ hasil perlakuan ultrasonik, dan juga fasa bongkah paduan $\mathrm{Fe}-\mathrm{Cr}$ lebih stabil diperoleh dengan serbuk paduan mikro $\mathrm{Fe}-\mathrm{Cr}$ hasil metode ultrasonik. Proses sintering pada penelitian ini menghasilkan paduan larutan padat $\mathrm{Fe}-\mathrm{Cr}$ sesuai dengan teori Hume-Rothery rules [20]. Pada penelitian lain, paduan berbasis Fe juga telah berhasil dibuat dari serbuk besi sponge, sebuk Nikel, dan serbuk grafit yang dikompaksi bersama dengan lubrikan zinc stearate melalui sintering konvensional dan microwave dengan suhu $11200 \mathrm{C}$ selama 30 menit [21]

\section{Nilai Kekerasan Bongkah Paduan Fe-Cr Hasil Sintering}

Efek sintering terhadap konsolidasi green $\mathrm{Fe}-\mathrm{Cr}$ memberikan nilai kekerasan seperti ditampilkan pada Gambar 6 kenaikan nilai kekerasan seperti pada Gambar 6. Terlihat bahwa telah terjadi penurunan nilai kekerasan pada sampel $\mathrm{B}$, hal ini kemungkinan dapat terjadi pada saat pengambilan data menggunakan mesin Vickers, dimana pada saat penekanan indentor tepat mengenai bagian yang 
keras dari sampel sehingga nilai kekerasan tersebut lebih tinggi dibandingkan dengan sampel lainnya. Nilai kekerasan dari semua jenis green $\mathrm{Fe}-\mathrm{Cr}$ setelah sintering. Sebagaimana telah dijelaskan pada bagian pembahasan strukturmikro, seperti pada Gambar 3, bahwa green $\mathrm{Fe}-\mathrm{Cr}$ tipe A terdiri dari partikel kecil $(\mathrm{Fe}, \mathrm{Cr}$ ) dan partikel besar (aglomerasi $\mathrm{Cr}$ ) sehingga pada saat kompaksi partikel kecil dan besar saling mengisi sehingga pada saat sintering penyatuan antar partikel akan lebih baik atau lebih rapat. Pada sintering sampai $1100^{\circ} \mathrm{C}$, terjadi pembentukan leher antar partikel atau penggabungan permukaan partikel, sementara pada suhu tinggi $\left(1300{ }^{\circ} \mathrm{C}\right)$ terjadi difusi batas butir atau ke kisi dan terjadi pemadatan [20].

Tabel 2 Nilai kekerasan setelah sintering

\begin{tabular}{|l|l|l|}
\hline Sampel & $\begin{array}{l}\text { Pembebanan } \\
(\mathrm{Kg})\end{array}$ & $\begin{array}{l}\mathrm{HVN}_{\text {rata- }} \\
\text { rata }\end{array}$ \\
\hline $\begin{array}{l}\text { FC25 A5t2 } \\
\left(1100^{\circ} \mathrm{C}\right)\end{array}$ & 0.2 & 208 \\
\hline $\begin{array}{l}\mathrm{FC} 25 \mathrm{~A} 5 \mathrm{t} 2 \\
\left(1200^{\circ} \mathrm{C}\right)\end{array}$ & 0.2 & 151 \\
\hline $\begin{array}{l}\mathrm{FC} 25 \mathrm{~A} 5 \mathrm{t} 2 \\
\left(1300^{\circ} \mathrm{C}\right)\end{array}$ & 0.2 & 90 \\
\hline
\end{tabular}

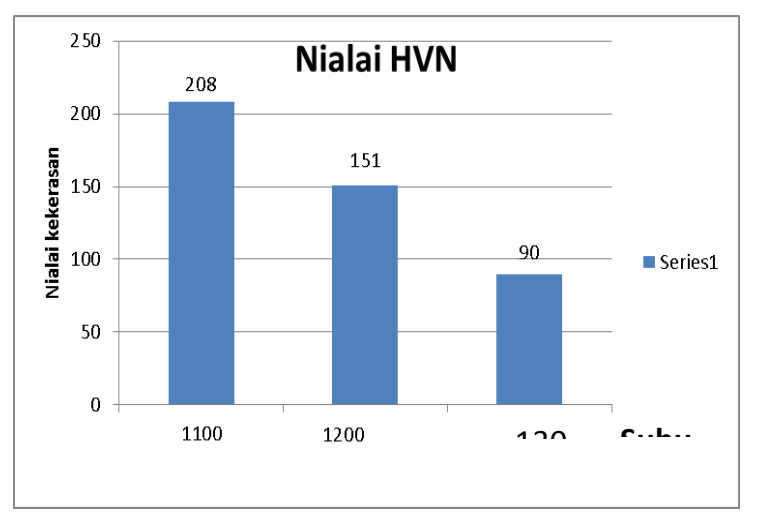

Gambar 6. Grafik Nilai kekerasan hasil sinter

Dengan kondisi awal seperti green dimana partikel saling mengisi maka Nilai kekerasa $\mathrm{Fe}-\mathrm{Cr}$ tipe $\mathrm{B}$ lebih besar dibanding Tipe $\mathrm{C}$ maupun Tipe D. Dilain pihak,partikel green Tipe D merupakan partikelpartikel kecil yang memiliki ukuran hampir sama sehingga tidak terjadi partikel yang saling mengisi. Dengan demikian Nilai kekerasan yang diperoleh lebih rendah. Nilai kekerasan (Gambar 7) hasil sintering dengan variasi suhu sinter $\mathrm{Fe}-\mathrm{Cr}$ menurun kekerasannya (Gambar 6). Penurunan ini terjadi karena pada proses sintering terjadi difusi antar partikel baik difusi permukaan dan difusi batas butir atau kekisi.

\section{IV.KESIMPULAN}

Bongkah paduan $\mathrm{Fe}-\mathrm{Cr}$ bisa diperoleh melalui kompaksi tanpa lubrikan terhadap serbuk paduan mikro Fe-Cr hasil perlakuan ultrasonik, dan diikuti sintering bertahap dalam kapsul kaca kuarsa dengan menggunakan tungku induksi. Fasa paduan $\mathrm{Fe}-\mathrm{Cr}$ yang diperoleh melalui variasi sintering lebih stabil dan konsisten dengan partikel awal paduan mikro Fe$\mathrm{Cr}$ seutuhnya dibandingkan dengan partikel awal paduan mikro $\mathrm{Fe}-\mathrm{Cr}$ sebagian. Bongkah paduan Fe$\mathrm{Cr}$ yang diperoleh merupakan larutan padat. Proses variasi sintering melalui suhu $1100^{\circ} \mathrm{C}$ sampai suhu $1300^{\circ} \mathrm{C}$ terhadap partikel serbuk $\mathrm{Fe}-\mathrm{Cr}$ yang berbeda proses sinternya akan memberikan nilai kekerasan yang berbeda pada bongkah paduan $\mathrm{Fe}-\mathrm{Cr}$ lebih besar dibandingkan dengan ukuran partikel yang hampir sama. Bongkah paduan $\mathrm{Fe}-\mathrm{Cr}$ yang diperoleh merupakan paduan $\mathrm{Fe}-\mathrm{Cr}$ homogen dan tanpa oksida. Dengan demikian pembuatan bongkah paduan $\mathrm{Fe}-\mathrm{Cr}$ homogeny dan tanpa oksida dapat dilakukan melalui metode ultrasonik dan bisa mengatasi permasalahan yang ditemui pada metode yang ada saat ini.

\section{DAFTAR ACUAN}

[1]. I.Antepara, I. Villarreal, L.M. RodríguezMartínez, N. Lecanda, U. Castro, and A. Laresgoiti, "Evaluation of ferritic steels for use as interconnects and porous metal supports in IT-SOFCs." Journal of Power Sources 151, pp 103- 107.2005.

[2]. R. Nowosielski, R. Babilas, "Fe-based bulk metallic glasses prepared by centrifugal casting method."Journal of Achievements in Materials and Manufacturing Engineering, vol. 48, Issue 2, pp. 153-160, Oct. 2011.

[3] A. Venskutonis, W. Glatz and G. Kunschert, "P/M Processing of ODS Cr- and FeCr-based alloys for Solid Oxide Fuel CellApplications." in 16th Plansee seminar: powder metallurgical high performance materials, 2005, pp.534-544.

[4]. S. Darwin, S. K. Deni, H. Saryanto, H. Sulaiman, M. A. Othman, and U. Pudji. "Oxidation Resistance of Fe80Cr20 Alloys Treated by Rare Earth 
Element Ion Implantation." inAIP Conference Proceedings, vol. 1394, 2010, pp. 90-102.

[5]. J. C. Hwan, L. H. Gyou, K. C. Joong, and S. B. Bhaduri. "Synthesis of $\mathrm{Cu}-\mathrm{Ni}$ alloy powder directly from metal salts solution." Journal of Nanoparticle Research, vol.5, pp.383-388. 2003.

[6]. D. J. D Silva, A. Silva, R. Machado, A. P. Paulo, Wendhause, "Processing of The Fe3Si Alloy From Prealloyed Powder Fe45Si by Injection Metal Molding." Materials Science Forum, vol. 591-593, pp 86-90. 2008.

[7]. L.A. P. Maqueda,A. Duran, and J. L. P. Rodrýguez, "Preparation of submicron talc particles by sonication." Appl. Clay Sci., vol.28, pp. 245-255. 2005.

[8]. P. R. Gogate, R. K. Tayal, and A. B. pandit."Cavitation: A Technology on the horizon."Current Science, vol. 91, no. 1, July. 2006.

[9]. R. Kuppa, V. S. Moholkar. "Physical features of ultrasound-enhanced heterogeneous permanganate oxidation." Ultrason Sonochem, vol.17, pp.123-131. 2010.

[10]. H. D. Hanh, N. T. Dong, C. Starvarache, K. Okitsu, Y. Maeda, and R. Nishimura. "Methanolysis of Triolein by Low Frequency Ultrasonic Irradiation."Energy Converse. Manage., vol. 49, pp. 276-280.2008.

[11]. M. Thirunavukkarasu and N. Kanagathara."Ultrasonic Studies on NonAqueous Solutions of Carbon Tetra Chloride in Toluene." International Journal of Chemistry Research, vol. 2, Issue 4. 2011.

[12]. M. Silalahi,A. Dimyati, S. Harjanto, P. Untoro, B.Suharno. "Microalloying of FeCr by using Ultrasonic Irradiation.(dalam pengajuan ke International Journal of Technology).

[13]. W. Pilarczyk, R. Nowosielski, and A. Pilarczyk."The structural study of Ti-Si-C alloys produced by mechanical alloying method." Archives ofMaterials Science and Engineering, vol. 38, pp.78-84.2009.

[14]. H. F. Sun, X. W. Li, J. Feng, W. Fang. "Characterization of TiAl-based alloy with highcontent $\mathrm{Nb}$ by powder metallurgy,"

Trans.Nonferrous Met. Soc. China, vol. 22, pp. s491-s495.2012.

[15]. ICDD, Software PCPDFWIN VERSION 1.30 (C) Copyright 1997

[16]. K. T. Jacob, S. Raj, and L. Rannesh. "Vegard's law: a fundamental relation or an approximation?"International Journal of Materials Research, vol.9, pp. 776-779. 2007.

[17]. F. Izumi. "Rietveld Analysis System RIETAN, A Software Package for the Pietan Analysis and Simulation of X-ray and Neutron Diffraction Patterns." Rigaku J., vol.6, no.1, pp. 10. 1989.

[18]. S. Suminta dan E. Kartini. "Analisis Struktur Komposit (AgI)X (AgPO3)1-X Dengan Metode Rietveld." Jurnal Sains Materi Indonesia, pp. 196 - 201, Oct. 2006.

[19]. S. J. L. Kang. Sintering Densification, Grain Growth \& Microstructure. Elsevier, 2005, pp. 39-50.

[20]. R. Abbhaschian, L. Abbhaschian, R. E. R. Hill. Physical Metallurgy Principles, fourth edition. Cengage Learning, 2008, pp. 261-26.

[21]. A. R. Annamalai, A. Upadhaya, and D. Agarwal. "Effect of heating mode on sintering of ferrous compacts through powder metallurgy route."International Heat Treatment and SurfaceEngineering, vol. 5, no. 4, pp. 155-160. 2011 